\title{
1. Past and future reform challenges for CESEE and Europe at large
}

\section{Ewald Nowotny, Doris Ritzberger-Grünwald and Helene Schuberth}

The aim of this book is to collect assessments of achievements and failures of past structural policies with a view to adapting them so that such policies help us to address the remaining or newly emerging challenges more effectively. The book has also been designed to depart from the beaten track and to shed some light on more inclusive growth strategies. Moreover, this book has a specific, albeit not exclusive, focus on the area of Central, Eastern and Southeastern Europe (CESEE), not least because this region has - by and large successfully - gone through a profound transition period. By transforming their economic and political systems, the CESEE countries have, so to speak, implemented the basis, or the 'mother' of all structural reforms.

Now, what is meant by 'structural reforms'? The term 'structure' refers to an arrangement of individual elements that form a complex phenomenon. In the case of an economy, structural reform could thus relate to any deliberate change within or between its sectors, factors or institutions. However, in the 1950s, this term acquired specific significance when the International Monetary Fund (IMF) and the World Bank introduced the notion of 'structural adjustment' to describe preconditions for receiving emergency loans, including trade liberalization, fiscal consolidation and the elimination of price controls as well as attracting foreign direct investment (FDI) and fighting corruption. Over the years, 'structural reforms' has more generally become a code for deregulation, liberalization and privatization.

Looking back, structural policies appear to have been advocated as a panacea for growth in Europe rather often, while monetary and fiscal policies were considered as having a stimulating effect on the economy in the short term only. But the experience since the onset of the financial and economic crisis in 2007-2008 seems to indicate that the better performance of the United States of America (USA) in terms of 
economic growth compared with the euro area might partly be attributed to different degrees of responses in terms of macroeconomic policy instruments. This divergence may reflect the fact that the monetary and fiscal policy reaction to the crisis came at a faster pace in the United States than in Europe, and that policy-makers took more decisive action in the United States than in Europe - which happened for a number of reasons. At the same time, however, we should not underestimate the macro effects that ensue from differences in the governance of the two monetary unions and effects stemming from divergent structures of the economies in general. With that in mind, institutional reform of Economic and Monetary Union (EMU) as a whole is a structural reform project that is crucial for the euro area, in particular with regard to complementing it with a Fiscal Union. This is a long-term project, but efforts to further deepen the European Monetary Union have been stepped up following the outbreak of the financial and economic crisis in Europe in 2008. Although we central bankers are more involved in the no less important completion of the Banking Union, we certainly welcome proposals toward more fiscal risk-sharing, that is, through a kind of macroeconomic stabilization function. As such, this book will also contribute to the institutional debate on the state of EMU (Gabrisch, Chapter 16). European institutions have made important headway since the crisis, with the crisis being an important contributing factor to the reform momentum. In order to receive support for necessary integration steps, social aspects need to be addressed with great care (Puntscher Riekmann, Chapter 3; Csaba, Chapter 15). Europe faces new social and economic challenges, such as globalization, digitization, demographic change, inequality and divergence. Institutionally, the European Union's 'Pillar of Social Rights' provides a vision for the rights of workers and citizens (Fischer, Chapter 4). Additionally, the European Commission has raised the idea of providing financial incentives for structural reforms, recognizing their short-term costs while accruing their positive spillovers to the rest of the Union. Naturally, for reforms to be sustainable and efficient over the long run, domestic factors come into play. As such, the European Commission has addressed this issue through an overhaul of its surveillance tools to better monitor vulnerabilities in the member states (Vinhas de Souza et al., Chapter 17).

Both monetary and fiscal policies rely on economic structures that are capable of absorbing any given stimulus. After all, macroeconomic measures can only exploit the long-term growth potential shaped by microeconomic conditions. In other words, structural reforms ensure the functioning of the monetary transmission mechanism and thus help to create fiscal space. In turn, monetary and fiscal expansion provide some 
flexibility in dealing with the short-term costs of structural reforms such as contractionary and unwanted distributional effects.

Moreover, in a Monetary Union, structural policies that keep costs and wages flexible and production factors mobile enable the economies of individual member states to swiftly adjust to asymmetric shocks. However, flexibility does not necessarily imply a decentralized structure. Just take the Austrian wage bargaining system as an example. With a collective bargaining coverage rate of 98 per cent, the system is certainly among the most centralized in the world. Yet, in terms of outcome, Austrian employees' wages are sufficiently flexible so as to enable comparably low unemployment rates in Europe. There is a simple explanation for this puzzle: strong umbrella organizations of trade unions and employer associations make sure that sectoral wage agreements always take nationwide rather than sector-wide productivity increases into account. What is more, this tried and tested consensual practice extends far beyond wage bargaining. The Austrian Social Partnership might not be the fastest-moving organization, but it certainly provides the ownership needed for pragmatic and sustainable structural reforms. In contrast, labour market regimes with very little employment protection, for instance, tend to be less conducive to the long-run accumulation of firm-specific knowledge. As research has shown, this type of productivity-enhancing innovation is, however, vital for a substantial industrial sector to survive in a high-wage economy (see Kleinknecht et al. 2014).

Overall, the CESEE region experienced a remarkable convergence process, which has been resumed after having been temporarily stalled by the crisis. Structural reforms definitely played an important role alongside macroeconomic stabilization, deep economic integration and a solid human capital base. Contributions to this book by colleagues from CESEE central banks shed light on the different experiences with such reforms and the additional reform needs, which only the crisis had revealed. What appears to be common to all is that synergies between sound fiscal and monetary policies have helped to overcome the downturn (see Makúch, Chapter 10; Virág, Chapter 11; Rusnok, Chapter 12; Strzelecki, Chapter 13). Of course, some countries have the advantage of being closer to European centres of industrial gravity. At the same time, differing country paths can also be explained by gaps in institutional quality. The European Union continues to be an important anchor for institutional reform, which can only be successful, however, in an environment of strong democracy and sound governance that works against corruption and 'state capture' (Mungiu-Pippidi, Chapter 14). After all, lack of trust in the government reduces political support for the next generation of reforms, which are to address challenges such as demographic headwinds (low fertility rates, 
emigration and brain drain) as well as technological innovation, energy efficiency and social fairness.

One area where convergence has been less convincing is real wages, even if we take account of slower productivity change, sinking unemployment rates and weaker wage growth in the rest of Europe (see Galgóczi 2017). On the one hand, low wages are not only a factor of competitiveness; on the other hand, low wages also dampen aggregate demand. With the skill component in production increasing, one wonders why the wage shares are still so low in the region. As evidenced by one of the contributions to this book (Ramskogler, Chapter 9), labour market dualities - given increased competition between temporary and permanent labour - have dampened wage growth in Europe overall and especially in CESEE.

Ultimately, we have learned quite a few lessons from the crisis (Draghi 2017): reforming labour markets without also reforming product markets intensifies deflationary pressures, in particular at the zero lower bound. Hence, comprehensive packaging of reforms is needed to reap the benefits intended. Trade-offs between growth and equality can be observed particularly in social and labour market reforms, rather than in product market reforms, which are addressed in Chapter 8 of this book (Causa). Ideally, reforms should also encompass attempts to make public administration more efficient and include a supportive macroeconomic policy mix (Arce et al. 2016). Furthermore, the right timing and sequencing of reform steps is equally important. In many instances, reforms create winners and losers, and ways to compensate the latter have to be implemented in the reform package.

Finally, this book also discusses the emerging protectionist attitudes and trade barriers, which could hamper the functioning of modern product markets, whereas sound standardization and regulations also appear to have beneficial effects if well designed (Taglioni, Chapter 6; Ghodsi et al., Chapter 7). Furthermore the book addresses the empirical evidence for the supposed growth effects of reforms (Bordon et al. 2016) as well as the conditions under which long-run gains may outpace likely short-run pain. Then there is the perennial question of whether there is a one-size-fits-all structure for economies. Of course, economic structures evolve hand in hand with the stage and path of economic development. As reflected by the World Bank's Doing Business ranking, which aims at measuring the outcome of business regulation, the European economies have been undergoing structural convergence, and have been becoming more and more similar. In the longer run, it remains to be seen whether these trends have been borne out by fundamentals. So far the good news is that 'structural laggards' are gradually catching up; some of the CESEE economies have even come to rank among the 'structural leaders' by certain standards. 


\section{REFERENCES}

Arce, O., S. Hurtado and C. Thomas (2016), 'Policy spillovers and synergies in a monetary union', International Journal of Central Banking, 12 (3), 219-77.

Bordon, A.R., C. Ebeke and K. Shirono (2016), 'When do structural reforms work? On the role of the business cycle and macroeconomic policies', IMF Working Paper, WP/16/62.

Draghi, M. (2017), 'Structural reforms in the euro area', Introductory remarks by Mario Draghi, President of the European Central Bank, at the ECB conference Structural Reforms in the Euro Area, Frankfurt am Main, 18 October.

Galgóczi, B. (2017), 'Why Central and Eastern Europe needs a pay rise', European Trade Union Institute Working Paper 2017.01.

Kleinknecht, A., F.N. van Schaik and H. Zhou (2014), 'Is flexible labour good for innovation?', Cambridge Journal of Economics, 38 (5), 1207-19. 